\title{
Relating Phage Genomes to Helicobacter pylori Population Structure: General Steps Using Whole-Genome Sequencing Data
}

\author{
Filipa F. Vale ${ }^{1, *}$ and Philippe Lehours $2,3, * \mathbb{D}$ \\ 1 Host-Pathogen Interactions Unit, Research Institute for Medicines (iMed-ULisboa), Faculdade de Farmácia, \\ Universidade de Lisboa, 1649-003 Lisboa, Portugal \\ 2 Laboratoire de Bacteriologie, Centre National de Référence des Campylobacters et Hélicobacters, Place \\ Amélie Raba Léon, 33076 Bordeaux, France \\ 3 INSERM U1053-UMR Bordeaux Research in Translational Oncology, BaRITOn, 33000 Bordeaux, France \\ * Correspondence: vale.filipa@gmail.com or f.vale@ff.ul.pt (F.F.V.); philippe.lehours@u-bordeaux.fr (P.L.); \\ Tel.: +351-217-946-494 (F.F.V.)
}

Received: 16 April 2018; Accepted: 15 June 2018; Published: 21 June 2018

\begin{abstract}
The review uses the Helicobacter pylori, the gastric bacterium that colonizes the human stomach, to address how to obtain information from bacterial genomes about prophage biology. In a time of continuous growing number of genomes available, this review provides tools to explore genomes for prophage presence, or other mobile genetic elements and virulence factors. The review starts by covering the genetic diversity of H. pylori and then moves to the biologic basis and the bioinformatics approaches used for studding the H. pylori phage biology from their genomes and how this is related with the bacterial population structure. Aspects concerning H. pylori prophage biology, evolution and phylogeography are discussed.
\end{abstract}

Keywords: phage; genome; phylogeography; Helicobacter pylori; evolution

\section{Introduction}

H. pylori is a Gram-negative bacterium that colonizes about half of the human population and is associated with several gastrointestinal diseases, such as gastritis (all cases), peptic ulcer ( $20 \%$ of the infected individuals), and in rare cases gastric cancer (1\%) and gastric MALT (Mucosa Associated Lymphoid Tissue) lymphoma $(<1 \%)[1]$. H. pylori shares a co-evolutionary history with the human host presenting a similar phylogeographic structure, which allows the reconstruction of human migrations [2,3]. H. pylori is characterized by its high genome diversity attributed to high mutation and recombination rates $[4,5]$. H. pylori presents an extraordinary diversity and high number of restriction-modification systems [6,7], which appear to inhibit import of heterologous DNA, but not homeologous recombination [8] that is very frequent in H. pylori [9]. Another source of genetic diversity in $H$. pylori arrives from mobile genomic elements, that present their own characteristic phylogeographic signal $[10,11]$. Prophages are widespread in the bacterial world and can be transferred to new hosts by horizontal gene transfer, which has been suggested to be pervasive in natural bacterial populations [12]. The aim of this review is to revisit $H$. pylori prophages and to provide tools for their study, especially focusing on how phage genomes are related with the bacterial population structure.

\section{H. pylori Population Structure and Human Migrations}

The study of seven housekeeping genes of $H$. pylori has been widely used to characterize the strains. The genes used for genes multilocus sequence typing (MLST) are atpA, efp, mutY, ppa, trpC, 
ure A and yphC [13]. The Bayesian clustering of these seven housekeeping genes applied to hundreds of strains from distinct geographic regions [2,14] revealed the presence of seven modern populations of $H$. pylori that clusters according to the geographic origin of the bacterium and its host (reviewed in [15-17]). The seven modern populations of H. pylori, hpAfrica2, hpAfrica1, hpNEAfrica, hpSahul, hpAsia2, hpEurope and hpEastAsia (Figure 1a,b), evidences that H. pylori and man co-evolved together, since they went "out of Africa" [2,3,14]. Each of these populations may be divided into subpopulations. For example hpAfrica1 is currently divided in hspSAfrica, hspWAfrica and hspCAfrica. The structured population provided strong evidence of ancient ancestry in Africa and of co-evolution with the human host since then. The original Human migration from Africa to the Middle East is estimated to have occurred 60,000-150,000 years ago and then independently to Europe and Asia [18-20].

H. pylori is a highly recombinogenic species [21]. Considering that recombination requires physical exchange of genomic DNA, recombination is more evident within populations than among populations [22]. While mutations are passed vertically to the offspring, recombination occurs between unrelated organisms that can create homoplasies, i.e., a similar sequence acquired from an unrelated lineage. This form of convergent evolution may biases the reconstructions of clonal phylogenies. This effect is observable in Figure 1a where branches separating strains are much longer than the ones separating populations [22]. Figure $1 \mathrm{~b}$ shows the resulting population assigned using the number of bacterial populations ( $\mathrm{K}=7$ ) using the program STRUCTURE, that uses a Bayesian approach. This program is run for several values of $K$ and in each run, for each $K$, a Markov Chain Monte Carlo simulation of thousand of iterations approximate the posterior probability of $K$. The number of populations $(\mathrm{K})$ that best clusters the data presents simultaneity higher posterior probability and is biologically interesting, i.e., correspond to real populations [23].

Next Generation Sequencing (NGS) is accelerating biological research in many areas such as genomics, transcriptomics, metagenomics, proteogenomics, gene expression analysis, noncoding RNA discovery, Single Nucleotide Polymorphism (SNP) detection, identification of protein binding sites, among others [24,25]. The increasing number of $H$. pylori genomes available provides a mean to obtain more information about its phylogeny. This is the case of the overcome of the difficulty in inferring the population structure due to high recombination rate found in H. pylori. Briefly, a method called chromosome painting in silico [26] was used to detect the transfer of DNA sequence chunks between genomes through homologous recombination throughout the genome [5]. A co-ancestry matrix is generated showing the expected number of chromosome chunks imported from a donor to a recipient genome. The matrix is then used to assign each strain to a subgroup using fineSTRUCTURE clustering algorithm [26]. This method revealed a finer population structure than the one based on the genes used by MLST typing $[5,27]$.

\section{Ancestral H. pylori Populations}

The STRUCTURE software has three model options, the "no admixture model", the "admixture model" and the "linkage model". The selection of the most appropriate model depends on the user's data and study objectives. The "no admixture model" is the simplest case where each individual is assumed to have originated in a single population, whereas when there is prior knowledge about the origin of the populations under study and there is no reason to consider each population as completely discrete, the "admixture model" is appropriate. The "linkage model" is like the admixture model, but linked loci are more likely to come from the same population. The linkage model relies on linkage disequilibrium - the nonrandom association of alleles at different loci-that is a sensitive indicator of the population genetic forces that structure a genome [23]. There are currently six ancestral or precursor populations inferred to $H$. pylori using the linkage model of STRUCTURE (Figure 2) to analyze the seven housekeeping genes used for MLST. These are Ancestral Sahul, Ancestral EastAsia, Ancestral Europe 1 (AE1), Ancestral Europe 2 (AE2), Ancestral Africa1 and Ancestral Africa2 [2,22,28]. Modern populations were produced by admixture of ancient populations. 


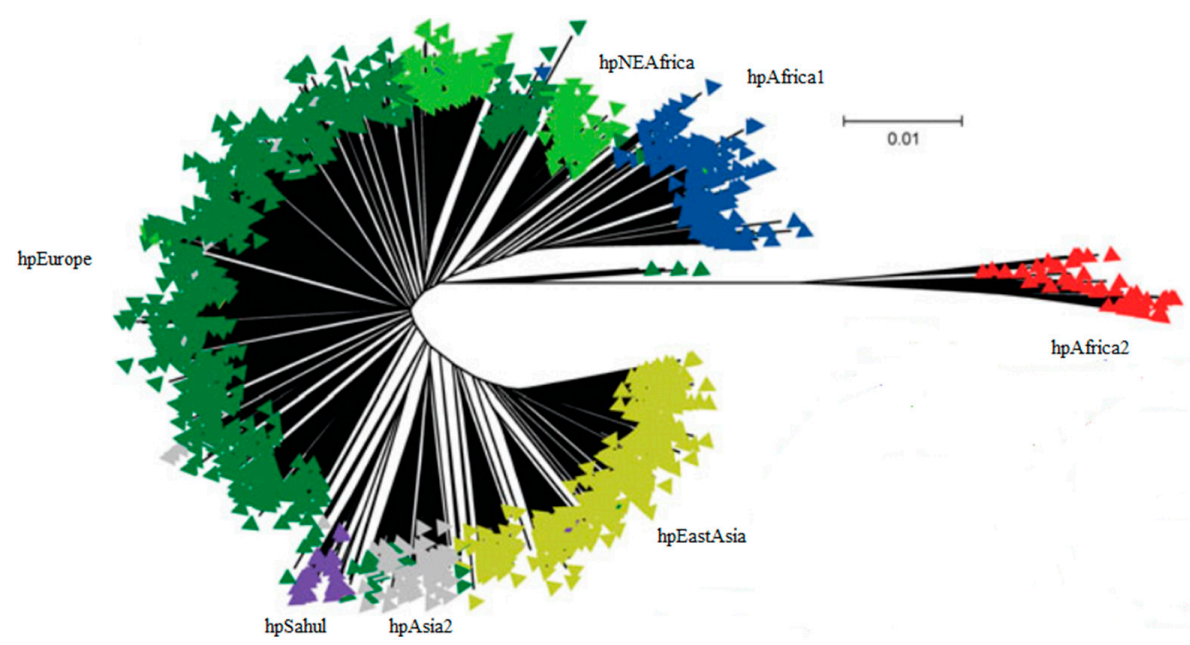

(a)

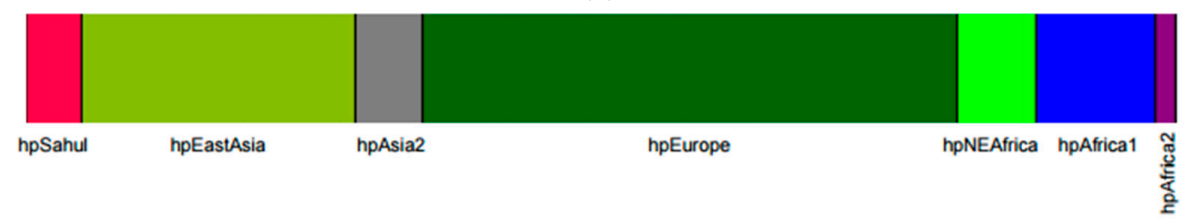

(b)

Figure 1. Worldwide population structure of H. pylori: (a) Neighbor-joining tree using Kimura two-parameter model of the concatenated H. pylori housekeeping genes (adapted with permission from [22]); (b) DISTRUCT plot of the Bayesian assignment of H. pylori to populations using STRUCTURE V2.0 with no admixture model, where each isolate is represented by a thin line that is color coded according to the population assignment (adapted with permission from [3]).

The case of hpEurope is particularly interesting, as this population is a recombinant of mainly AE1 and AE2 [2]. AE1 probably entered Europe via central or southern Asia, while AE2 entered Europe via Northeast Africa or Southern Europe [2,29]. The strains from India assigned to hpEurope revealed residual evidence of AE2, but presented a higher influence of ancestral EastAsia (Figure 2). This influence of ancestral EastAsia was still observed, even that in a small scale, for countries where AE1 is more predominant, favoring the entering of AE1 through Asia. Southern European countries presented a higher proportion of AE2 (Figure 2). Interestingly, Iberian countries also present influence of the recombination with ancestral Africa1, that is even higher than AE1 in a few hpEurope strains from African Portuguese speaking countries [29].

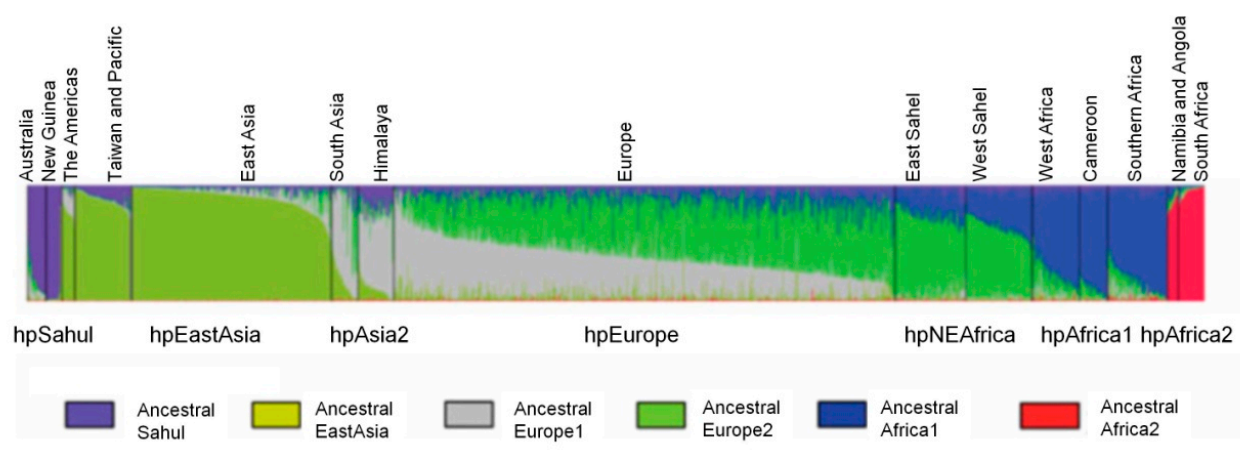

(a)

Figure 2. Cont. 


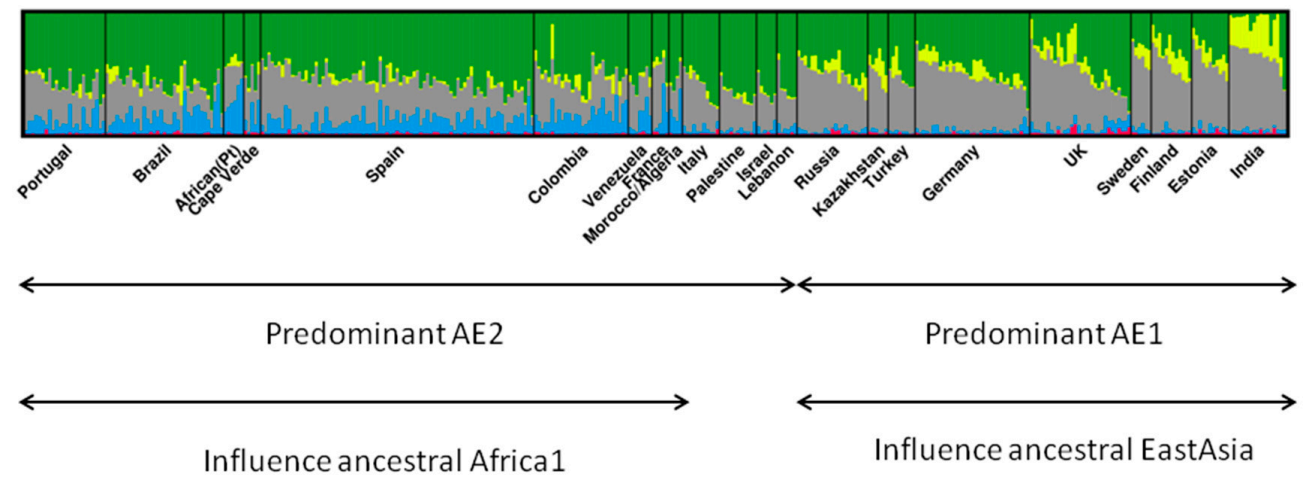

Ancestral Europe $1 \square$ Ancestral Europe $2 \quad$ Ancestral Africa $1 \quad$ Ancestral EastAsia $\square$ Ancestral Africa2

(b)

Figure 2. Ancestral populations of H. pylori. Each vertical line represents a strain. (a). General 6 ancestral populations of H. pylori. Modern H. pylori populations result from the admixture of ancestral populations (adapted with permission from [22]); (b). Detailed ancestral populations found in Europe. All hpEurope strains are recombinants of AE1 and AE2, but southwest Europe strains are additionally a product of recombination with ancestral Africa1 (adapted with permission from [29]).

The spread of AE2 to Europe may have occurred during the Paleolithic population expansion from the "Atlantic zone" (southwestern Europe) 10,000-15,000 years ago, after the Last Glacial Maximum [30]. It is also feasible that a second wave of migration from Africa to Iberia during the Arab Empire (711-1249) introduced ancestral Africa1. During the Arab empire the Iberia peninsula colonizers were mainly Berbers from North Africa, and not Arabs, which is in agreement with ancestral proportions of each population found in Iberian countries and northern Africa (AE1, AE2 and ancestral Africa1) and middle east (AE1 and AE2, but not ancestral Africa1). Before this period there was a commercial trade between Iberia peninsula and Mediterranean nations, which also may explain the influence of ancestral Africa1 [29]. The exact way AE1 and AE2 recombination occurred is controversial, but may arose latter than previously expected, since the 5000 years old Iceman mummy found in Italian border presented only AE1 ancestry [31].

\section{Bacteriophages}

Bacteriophages may present a lytic or lysogenic life cycle. The former lyse the bacterial host cell after viral replication, allowing the release of newly formed phage particles. The latter constitute lysogenic or temperate phages, which are able to switch between lytic and lysogenic cycles. If pursuing the lysogenic cycle, the phage genome is integrated in the bacterial genome and gains the designation of prophage. These continuous process of phage insertion and excision from the bacterial host genome can provide a mean of changing various genes among bacteria, some of which may provide an advantage to the host cell, for instance promoting antibiotic resistance or virulence [32]. Phage integrases and excisionases mediate integration and excision from the host cell genome at specific attachment sites of bacteria (attB) and phage (attP) genomes, respectively [33]. Another less frequent phage life cycle is pseudolysogeny, described as an unstable situation in which the phage genome fails to replicate (lytic cycle) or become established as a prophage (lysogenic cycle). Pseudolysogeny has been associated with nutrient-deprived conditions, that impairs DNA replication or protein synthesis, during which the phage genome remains for an extended period of time as a non-integrated preprophage, similar to an episome [33,34]. According to this hypothesis when the nutritional status is restored the phage enters either a lysogenic or a lytic life cycle [33].

Despite the putative bacterium-phage evolutionary conflict, phages profit from promoting the survival and proliferation of their hosts [33]. Likewise, prophages may harbor cargo genes, or 
"morons", which while are not essential for the phage, benefits the host. Some very well known lysogenic phages carry genes that enhance the virulence of the bacterial host [35]. In addition, the deletion of prophages from Escherichia coli revealed that prophages improved the surviving under adverse environmental conditions, including acid stress or early biofilm formation [36]. Prophages may therefore work as gene reservoirs, many of which benefit pathogens, in ways which are only just beginning to be determined [37]. In a hostile environment, such as the human stomach, any metabolic advantage or resistance/tolerance mechanism provided by prophages should be important in improving bacterial host competitiveness. Prophage induction may also be used as a weapon for colonizing new niches [38], displacing native strains, although this strategy may be rarely used, first by the creation of lysogens in the susceptible population, second by the cost of cell lysis in a fraction of the population, and third due to the purifying selection of prophages [39]. Taken together, these properties may explain why prophages are more frequent in pathogenic bacteria [40]. Host-prophage driven selection and genetic flux occurs even for prophage genes that do not effect host physiology [39]. Thus, the role of prophages in disease establishment is being progressively acknowledged.

\subsection{H. pylori Phages and Prophages}

One of the remarkable characteristics of $H$. pylori is the extensive genetic diversity between different strains $[6,7,14,41,42]$. This diversity has been attributed to an elevated high mutation rate, impaired DNA repair, lateral DNA transfer and frequent recombination events [43]. Horizontal gene transfer, the movement of genetic material between different genomes, constitutes a key evolutionary force that shapes bacterial genomes and may contribute to niche adaptation through gaining of genes that provide selective advantages [44,45]. Importantly, horizontal gene transfer plays a role in spreading antibiotic resistance $[46,47]$. Plasmids, transposons and phages are mobile genetic elements that mediate horizontal gene transfer, all of them known to be present in H. pylori. The horizontal gene transfer may be mediated by transformation (transfer of a naked DNA fragment), conjugation (direct transfer between two bacteria temporarily in physical contact) and transduction (transport of bacterial DNA by phages), but also by membrane vesicles and autolysis [44]. Conjugation [43,48] and transformation $[49,50]$ have already been described for $H$. pylori, but not transduction. There are about $10^{31}$ phages on the planet, with phages exceeding bacteria in number by tenfold, but less than an estimated 1\% have been described [51]. Bacteriophage description in H. pylori is brief in the literature. The first descriptions of $H$. pylori phages came from the observation of micrographs where particles compatible with phages were observed (Figure 3) [52-56]. All but Figure $3 f$ appear to be icosaedric phage particles, which typically have an icosahedral capsid protein and a double stranded DNA genome. Based on their morphology only phages in Figure $3 \mathrm{a}, \mathrm{d}, \mathrm{g}$ are compatible with Corticoviridae and Tectiviridae, without tail but with a lipidic content; phages in Figure 3b,c,e show similarities with family Siphoviridae, having a long non-contractil tail; while phages in Figure 3f, considering the morphological filamentous form, are similar to Inoviridae, which harbor single stranded DNA small genomes. However, the nucleic acid of the filamentous phage present in Figure $3 \mathrm{f}$ was not isolated.

The development of the genomic studies, especially using high-throughput genome sequencing led to the first reports of prophages, some remnant [57], others apparently complete and capable of going through a lytic cycle [58-62]. A screening for prophages in public available genomes of $H$. pylori revealed the presence of prophage sequences ranging from 5.5 to $39.3 \mathrm{~Kb}$ [63]. Table 1 offers a compendium of $H$. pylori phage particles identified so far. Strains carrying prophages do not appear to have a higher pathogenicity or association with particular disease patterns $[10,58]$, but it has been suggested that the presence of phage orthologous genes correlates with the presence of $c a g A$ and/or vacA virulence genes [64]. Despite the putative bacterium-phage evolutionary conflict, phages profit from promoting the survival and proliferation of their hosts [33].

The intricate and complex co-evolutionary process shared by bacteria and their viruses is difficult to ascertain [51]. There are several evidences of this co-evolutionary process, some of which are: 
(i) phylogenetic agreement between integrase phage gene and MLST genes, both showing a similar phylogeographic segregation, although the existence of some differences; (ii) the probable acquisition of prophages before Helicobacter speciation, evidenced by the existence of prophage genes in other Helicobacter species, like Helicobacter acinonychis [65], Helicobacter felis [66], or Helicobacter bizzozeronii [67]; (iii) a similar genetic syntheny of phage genes of distinct lineages [58]; (iv) and, finally, the occurrence of prophage remnants in both $H$. pylori [68,69] and non-pylori Helicobacters, [70] suggesting phage inactivation by an ongoing phage decay process. It is feasible to accept that at any point a strain may be infected by a phage from a particular lineage, starting at this moment the interaction between phage and bacteria, meaning that the observation of a prophage in a genome does not offer information about how long it has been there. Nonetheless, the points highlighted above strongly suggest a prolonged co-evolutionary history [10].
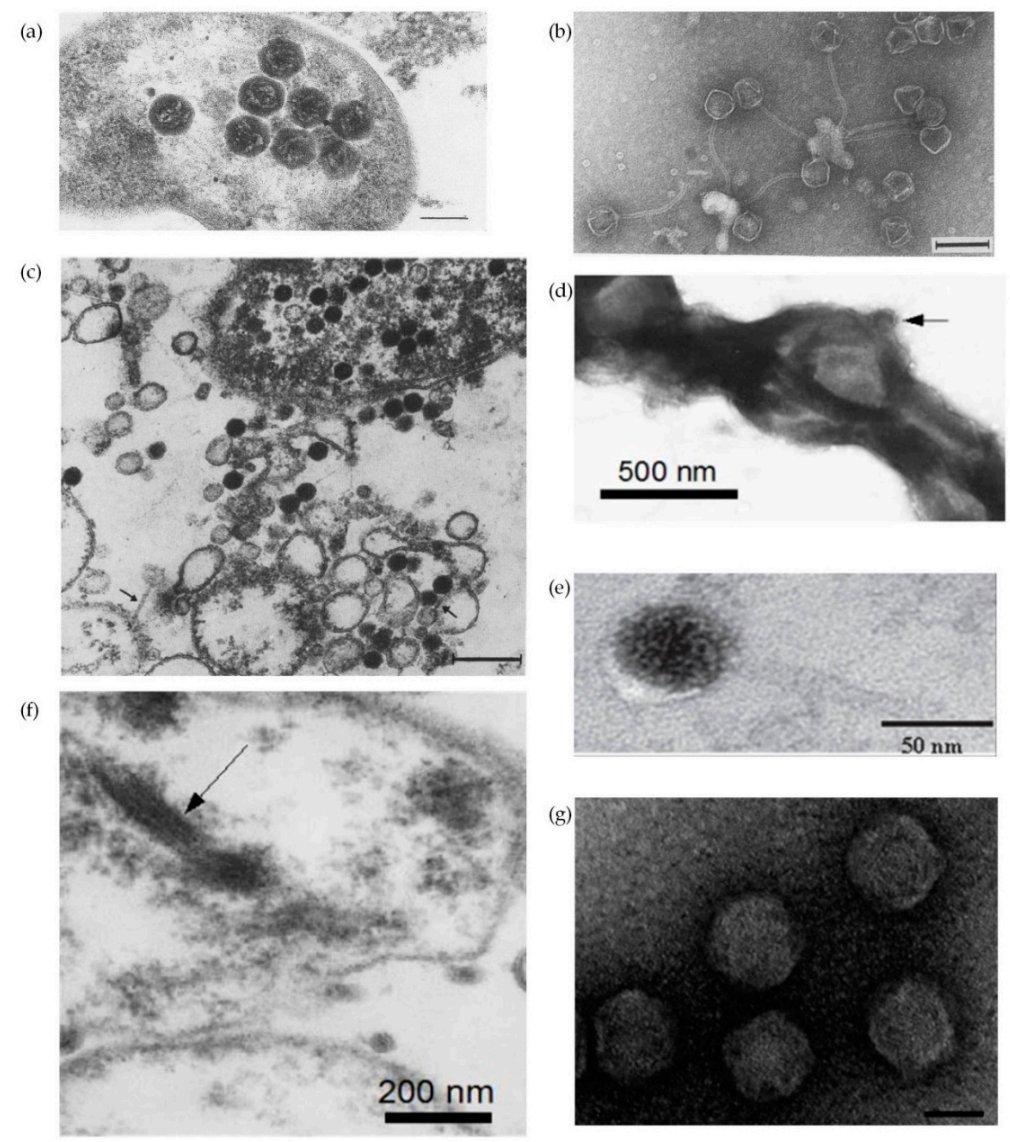

Figure 3. Electron micrographs of $H$. pylori phages: (a) Thin section of $H$. pylori carrying phage particles with phage head diameter of about $85 \mathrm{~nm}$. Bar $=100 \mathrm{~nm}$ (adapted with permission from [53]); (b) Negative staining of H. pylori phage HP1. Phage head diameter of about 50 to $60 \mathrm{~nm}$ and tail with $170 \mathrm{~nm}$ and a diameter of $9.5 \mathrm{~nm}$. Bar = $100 \mathrm{~nm}$ (adapted with permission from [56]); (c) Thin section of $H$. pylori evidencing cell with empty and filled phage heads. Phage head diameter with $(70 \pm 5) \times(60 \pm 4) \mathrm{nm}$ and tail with $120 \mathrm{~nm}$ long. Arrows point phage tails in extracellular phages. Bar $=200 \mathrm{~nm}$ (adapted with permission from [55]); (d) Negative staining of H. pylori cell with arrow pointing to a polyhedral phage-like particle with a diameter of about $100 \mathrm{~nm}$ without tail (adapted with permission from [54]); (e) Thin section of H. pylori phage phiHP33, presenting a total length of $150 \mathrm{~nm}$, a phage head diameter of $62.5 \mathrm{~nm}( \pm 7.3 \mathrm{~nm})$, and a tail with $92.4 \mathrm{~nm}( \pm 2.97 \mathrm{~nm})$ long and 5 to $6 \mathrm{~nm}$ in diameter (adapted with permission from [58]); (f) Arrow points to hypothetical $15 \mathrm{~nm}$ phage filamentous in H. pylori cell (adapted with permission from [54]); (g) Negative staining of intact H. pylori KHP30 phage particles with no tail and head diameter of $68.8 \mathrm{~nm}( \pm 2.3 \mathrm{~nm})$. Bar $=50 \mathrm{~nm}$ (adapted with permission from [61]). 
Table 1. Characteristics of H. pylori phages particles.

\begin{tabular}{ccccccc}
\hline Name & Family & $\begin{array}{c}\text { Gene } \\
\text { Number }\end{array}$ & $\begin{array}{c}\text { Genome } \\
\text { Size } \mathbf{( k b )}\end{array}$ & Gene Functions & $\begin{array}{c}\text { Head/Tail } \\
\text { Size (nm) }\end{array}$ & Reference \\
\hline HP1 & Siphoviridae & nd & 22 & nd & $50-60 / 170 \times 9.5$ & {$[56]$} \\
\hline phiHP33 & Siphoviridae & 27 & 24.6 & $\begin{array}{c}\text { regulation, replication, } \\
\text { structural, lysis }\end{array}$ & $55-70 / 92 \times 6$ & {$[58]$} \\
\hline KHP30 & $\begin{array}{c}\text { Corticoviridae/ } \\
\text { Tectiviridae * }\end{array}$ & 30 & 26.2 & $\begin{array}{c}\text { Integration } \\
\text { replication, structural, lysis }\end{array}$ & $67-71 /$ absent & {$[61]$} \\
\hline 1961P & Podoviridae & 33 & 26.8 & $\begin{array}{c}\text { Integration } \\
\text { replication, structural, lysis }\end{array}$ & $68-74 / 23 \times 13.3$ & {$[59]$} \\
\hline
\end{tabular}

* but with larger genome size and (pseudo)lysogenic cycle; nd-not determined.

\subsection{Contribution of Prophages Genomes to H. pylori Population Structure}

Interestingly, like their host, $H$. pylori prophages also present a phylogeographic distribution. The population to which prophages belong was determined by prophage sequence typing (PST), which targets two prophage genes (integrase and holin) of $H$. pylori and applies a Bayesian clustering analysis for the identification of distinct genetic populations. The prophage genes used by the PST method are the integrase (responsible for the integration of the phage genome into the bacterial chromosome) and holin (involved in cell lysis when a lytic cycle occurs). Currently there are 4 prophage populations described (Figure 4), hpAfrica1, hpEastAsia, hpNEurope and hpSWEurope [10,71].

\subsection{Phage Detection and Annotation}

Identification of phage genes is similar to any other gene annotation process. There are several annotation pipelines [72], such as RAST [73], Prokka [74] and others. Genome annotations starts by identifying genes, or more precisely open reading frames (ORF), i.e., identifying start and stop positions in same frame of the prokaryote genome, along with function identification. Predicting ORF is done using software like Glimmer [75] or GeneMark [76]. The next step consists in using these predictions and search databases, such as Genbank [77] and SwissProt [78], using mainly BLAST [79], or other programs. The accuracy of this step depends of the annotation software and the quality of the annotations already in the reference database [72,80]. To efficiently decrease annotation error comparison of results from multiple annotation services should be performed, interchanging information between annotation services [80]. There are, however, specific packages and web servers for detecting and inferring prophage presence and completeness. Search for homologous may be done in relevant protein viral databases, like Phantome (http:/ / www.phantome.org/), PHAST/PHASTER database [81], and VirSorter [82]. These packages include the first ones developed, namely Prophage Finder [83], Phage_Finder [84] and Prophinder [85]. Recently PHAST and PHASTER were developed performing 40 times faster and presenting results up to $15 \%$ more sensitive in comparison with the previous ones [81,86].

Other prophage identification tools have been described, such as PhiSpy [87] which analyzes several other sequence-based statistics to help identify novel phages (AT and GC skew, protein length and transcription strand directionality) that are not represented in existing phage databases, and VirSorter [82] that handles metagenomic data with improved performance for fragmented genomes. These tools may run locally like (PhiSpy, Phage_Finder, Prophage Finder), to access through a web-server (PHAST/PHASTER), or made available through cyberinfrastructure (iPlant Discovery Environment [88], a Web portal of iPlant's cyberinfrastructure that houses several apps for sequencing analysis and other data-intensive technologies) that provides a web-based user interface. The strategies applied by the above phage finder tools are based on databases of gene and protein sequences of phage origin and other typical sequences found in phages, such as attachment sites $a t t P$ and $a t t B$. Thus, finding novel prophages sequences is challenging when there is no counterpart 
in the database that serves the tool. Moreover, these tools allow to identify the contigs presenting phage sequences, but not necessary the complete phage sequence, which is rarely present in one contig only [89]. To overcome these limitations an additional step using BLAST with a query of a complete nucleotide phage sequence to check for homologies in the contigs is helpful. The BLAST analysis is not only useful to confirm the presence of a phage sequence, but also to determine the order of the contigs in the phage genome. Based on this predicted contig order, primers flanking the contigs can be designed to bridge and close the gaps in the assembly.

(a)

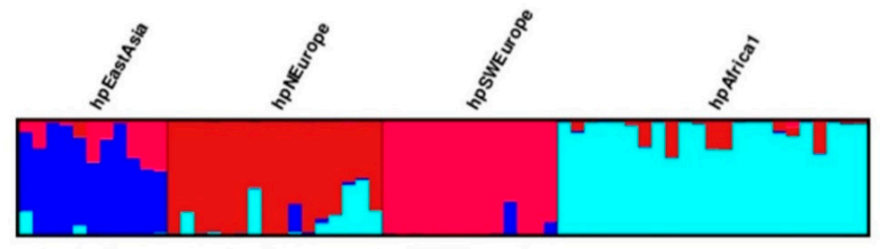

(b)
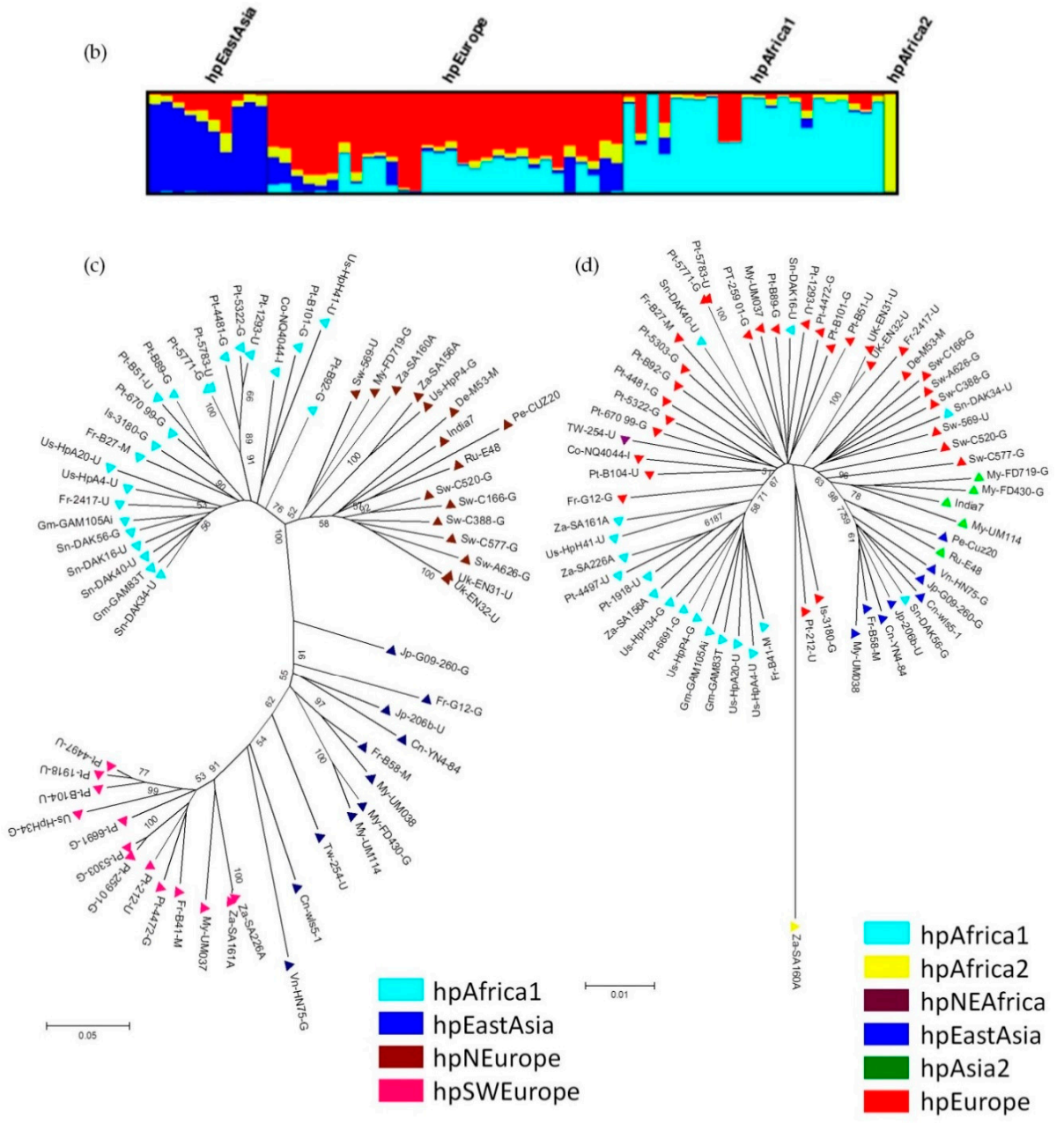

Figure 4. Population structure of $H$. pylori prophages: (a) DISTRUCT plot of Bayesian population assignments using STRUCTURE and an admixture model $(K=4)$ for prophages genes (PST); (b) Same methodology used for the sequences of seven housekeeping genes (MLST). Each bacterial isolate is depicted by a thin vertical line, which is divided into K colored segments representing the membership coefficients in each cluster; (c) Neighbour-joining tree (Kimura 2-parameter) of concatenated prophage sequences; (d) Neighbour-joining tree (Kimura 2-parameter) of concatenated sequences of MLST genes. In $\mathrm{C}$ and $\mathrm{D}$ the strains are colour-coded according to the population assignment by STRUCTURE using PST and MLST genes, respectively (adapted from [10]). 
Assembled prophages should then be annotated using general annotation pipelines, or specific for phage annotation, such as PHAST [81], Phages v. 1.0 (available online: http:/ /www.phantome.org/ PhageSeed/Phage.cgi?page=phast). Phage genomes typically have mosaic architectures and contain several small open reading frames of unknown function, approximately two-thirds the average size of bacterial genes, which is challenging for annotation and comparative analysis [90].

Available tools to predict the potential gene function include BLASTP (using local or NCBI databases) [79], HHPred (more sensitive then BLASTP and allowing protein structure prediction) [91], presence of conserved domains detected using BLAST, and pairwise comparisons of protein-coding genes to group genes by sequence similarity or conserved domains [92]. Other important aspect to assign gene function is genome synteny, since many of the genes appear in the same order and grouped by function. The gene functions of phage genes can be grouped in structure and assemble, DNA replication, life cycle regulation, cell lysis and other well characterized genes, like toxin/anti-toxin genes. Nevertheless, false positive identification cannot be ruled out and different approaches should be considered [90], keeping in mind that wet-lab experiments are the gold-standard.

Other available tools allow to predict the phage life cycle according to the protein function [93]. While integrase and excision genes favor the attribution of lysogenic cycle, the nature of structural proteins favors the identification of lytic cycle [93]. Using this tool, considering H. pylori phage genomes, all were confidently predicted as having a temperate life cycle. Other comparative genomics studies follow the general guidelines introduced above.

\subsection{Potential Use of Phages to Eradicate H. pylori}

The use of phages to deal with bacterial infections is older than the introduction of antibiotics, whose discovery limited the use and investigation in the field of phage therapy. Worldwide antibiotic resistance is increasing treatment challenges in general for bacteria and particularly for Gram-negatives like H. pylori. This global antibiotic crisis was recognized by the World Health Organization (WHO) that published in 2017 the first ever list of antibiotic-resistant priority pathogens for research and development of new antibiotics [94]. The list is mostly constituted by multi-resistant Gram-negative pathogens, including H. pylori, for which no new antibiotic class active can be anticipated in the near future. Phage therapy use lytic phages or their lytic lysins, to specifically treat infectious diseases caused by the phage host bacterium [95]. Phage therapy in its 100 years anniversary in light of its capability to kill susceptible organisms has attracted much attention as potential substitute for conventional antibiotics [96]. Phage therapy studies focusing H. pylori are a missing topic in the literature, but the continuous effort of fundamental research to describe and comprehend their gene function and role in phage-host co-evolution introduces the seed for future studies.

\section{Conclusions}

H. pylori, through the bacterium phylogeographic distribution, continues to provide insight about human migrations and admixture of populations, initially using Sanger sequencing of housekeeping and presently NGS technology. The later using the whole genome provides in-depth characterization of the population structure at finer level. Additionally, information from prophages genomes is related with the bacterial host population structure and may provide additionally information about subpopulations. In a time of continuous growing number of genomes available, the tools available for phage detection are important to find and characterize phages. Some of these tools can be adapted to explore genomes for other mobile genetic elements or virulence factors. Moreover, $H$. pylori phages may in the future be helpful to treat $H$. pylori infection.

Author Contributions: F.F.V. and P.L. outlined the review topics and manuscript organization; F.F.V. wrote the paper; P.L. revised the manuscript; both authors approved the submitted version.

Funding: This research received no external funding. 
Acknowledgments: Filipa F. Vale is recipient of a postdoctoral fellowship (SFRH/BPD/95125/2013) from the Fundação para a Ciência e a Tecnologia (FCT).

Conflicts of Interest: The authors declare no conflict of interest.

\section{Abbreviations}

MALT Mucosa Associated Lymphoid Tissue

MLST Multilocus Sequence Typing

NGS Next Generation Sequencing

ORF Open Reading Frame

PST Prophage Sequence Typing

SNP Single Nucleotide Polymorphism

\section{References}

1. Kusters, J.G.; van Vliet, A.H.; Kuipers, E.J. Pathogenesis of Helicobacter pylori infection. Clin. Microbiol. Rev. 2006, 19, 449-490. [CrossRef] [PubMed]

2. Falush, D.; Wirth, T.; Linz, B.; Pritchard, J.K.; Stephens, M.; Kidd, M.; Blaser, M.J.; Graham, D.Y.; Vacher, S.; Perez-Perez, G.I.; et al. Traces of human migrations in Helicobacter pylori populations. Science 2003, 299, 1582-1585. [CrossRef] [PubMed]

3. Moodley, Y.; Linz, B.; Yamaoka, Y.; Windsor, H.M.; Breurec, S.; Wu, J.; Maady, A.; Bernhöft, S.; Thiberge, J.; Phuanukoonnon, S.; et al. The peopling of the Pacific from a bacterial perspective. Science 2009, 323, 527-530. [CrossRef] [PubMed]

4. Suerbaum, S.; Josenhans, C. Helicobacter pylori evolution and phenotypic diversification in a changing host. Nat. Rev. Microbiol. 2007, 5, 441-452. [CrossRef] [PubMed]

5. Yahara, K.; Furuta, Y.; Oshima, K.; Yoshida, M.; Azuma, T.; Hattori, M.; Uchiyama, I.; Kobayashi, I. Chromosome painting in silico in a bacterial species reveals fine population structure. Mol. Biol. Evol. 2013, 30, 1454-1464. [CrossRef] [PubMed]

6. Vale, F.F.; Vitor, J.M. Genomic Methylation: A Tool for Typing Helicobacter pylori Isolates. Appl. Environ. Microbiol. 2007, 73, 4243-4249. [CrossRef] [PubMed]

7. Vale, F.F.; Encarnacao, P.; Vitor, J.M. A new algorithm for cluster analysis of genomic methylation: The Helicobacter pylori case. Bioinformatics 2008, 24, 383-388. [CrossRef] [PubMed]

8. Bubendorfer, S.; Krebes, J.; Yang, I.; Hage, E.; Schulz, T.F.; Bahlawane, C.; Didelot, X.; Suerbaum, S. Genome-wide analysis of chromosomal import patterns after natural transformation of Helicobacter pylori. Nat. Commun. 2016, 7, 11995. [CrossRef] [PubMed]

9. Berthenet, E.; Sheppard, S.; Vale, F.F. Recent "omics" advances in Helicobacter pylori. Helicobacter 2016, 21 (Suppl. 1), 14-18. [CrossRef] [PubMed]

10. Vale, F.F.; Vadivelu, J.; Oleastro, M.; Breurec, S.; Engstrand, L.; Perets, T.T.; Megraud, F.; Lehours, P. Dormant phages of Helicobacter pylori reveal distinct populations in Europe. Sci. Rep. 2015, 5, 14333. [CrossRef] [PubMed]

11. Olbermann, P.; Josenhans, C.; Moodley, Y.; Uhr, M.; Stamer, C.; Vauterin, M.; Suerbaum, S.; Achtman, M.; Linz, B. A global overview of the genetic and functional diversity in the Helicobacter pylori cag pathogenicity island. PLoS Genet. 2010, 6, e1001069. [CrossRef] [PubMed]

12. Toussaint, A.; Rice, P.A. Transposable phages, DNA reorganization and transfer. Curr. Opin. Microbiol. 2017, 38, 88-94. [CrossRef] [PubMed]

13. Achtman, M.; Azuma, T.; Berg, D.E.; Ito, Y.; Morelli, G.; Pan, Z.J.; Suebaum, S.; Thompson, S.A.; van der Ende, A.; van Doom, L.J. Recombination and clonal groupings within Helicobacter pylori from different geographical regions. Mol. Microbiol. 1999, 32, 459-470. [CrossRef] [PubMed]

14. Linz, B.; Balloux, F.; Moodley, Y.; Manica, A.; Liu, H.; Roumagnac, P.; Falush, D.; Stamer, C.; Prugnolle, F.; van der Merwe, S.W.; et al. An African origin for the intimate association between humans and Helicobacter pylori. Nature 2007, 445, 915-918. [CrossRef] [PubMed]

15. Suerbaum, S.; Achtman, M. Helicobacter pylori: Recombination, population structure and human migrations. Int. J. Med. Microbiol. 2004, 294, 133-139. [CrossRef] [PubMed] 
16. Suzuki, R.; Shiota, S.; Yamaoka, Y. Molecular epidemiology, population genetics, and pathogenic role of Helicobacter pylori. Infect. Genet. Evol. 2012, 12, 203-213. [CrossRef] [PubMed]

17. Megraud, F.; Lehours, P.; Vale, F.F. The history of Helicobacter pylori: From phylogeography to paleomicrobiology. Clin. Microbiol. Infect. 2016, 22, 922-927. [CrossRef] [PubMed]

18. Cavalli-Sforza, L.L.; Menozzi, P.; Piazza, A. The History and Geography of Human Genes; Abridged Paperback Edition; Princeton University Press: Princeton, NJ, USA, 1996.

19. DeMenocal, P.B.; Stringer, C. Human migration: Climate and the peopling of the world. Nature 2016, 538, 49-50. [CrossRef] [PubMed]

20. Moodley, Y.; Linz, B.; Bond, R.P.; Nieuwoudt, M.; Soodyall, H.; Schlebusch, C.M.; Bernhöft, S.; Hale, J.; Suerbaum, S.; Mugisha, L.; et al. Age of the association between Helicobacter pylori and man. PLoS Pathog. 2012, 8, e1002693. [CrossRef] [PubMed]

21. Suerbaum, S.; Smith, J.M.; Bapumia, K.; Morelli, G.; Smith, N.H.; Kunstmann, E.; Dyrek, I.; Achtman, M. Free recombination within Helicobacter pylori. Proc. Natl. Acad. Sci. USA 1998, 95, 12619-12624. [CrossRef] [PubMed]

22. Moodley, Y. Helicobacter pylori: Genetics, recombination, population structure, and human migrations. In Helicobacter pylori Research from Bench to Bedside; Backert, S., Yamaoka, Y., Eds.; Springer: Berlin, Germany, 2016; pp. 3-27.

23. Pritchard, J.K.; Stephens, M.; Donnelly, P. Inference of population structure using multilocus genotype data. Genetics 2000, 155, 945-959. [PubMed]

24. El-Metwally, S.; Hamza, T.; Zakaria, M.; Helmy, M. Next-generation sequence assembly: Four stages of data processing and computational challenges. PLoS Comput. Biol. 2013, 9, e1003345. [CrossRef] [PubMed]

25. Deurenberg, R.H.; Bathoorn, E.; Chlebowicz, M.A.; Couto, N.; Ferdous, M.; García-Cobos, S.; Kooistra-Smid, A.M.; Raangs, E.C.; Rosema, S.; Veloo, A.C.; et al. Application of next generation sequencing in clinical microbiology and infection prevention. J. Biotechnol. 2017, 243, 16-24. [CrossRef] [PubMed]

26. Lawson, D.J.; Hellenthal, G.; Myers, S.; Falush, D. Inference of population structure using dense haplotype data. PLoS Genet. 2012, 8, e1002453. [CrossRef] [PubMed]

27. Thorell, K.; Yahara, K.; Berthenet, E.; Lawson, D.J.; Mikhail, J.; Kato, I.; Mendez, A.; Rizzato, C.; Bravo, M.M.; Suzuki, R.; et al. Rapid evolution of distinct Helicobacter pylori subpopulations in the Americas. PLoS Genet. 2017, 13, e1006546. [CrossRef] [PubMed]

28. Breurec, S.; Guillard, B.; Hem, S.; Brisse, S.; Dieye, F.B.; Huerre, M.; Oung, C.; Raymond, J.; Tan, T.S.; Thiberge, J.; et al. Evolutionary history of Helicobacter pylori sequences reflect past human migrations in Southeast Asia. PLoS ONE 2011, 6, e22058. [CrossRef] [PubMed]

29. Oleastro, M.; Rocha, R.; Vale, F.F. Population genetic structure of Helicobacter pylori strains from Portuguese-speaking countries. Helicobacter 2017, 22, 12382. [CrossRef] [PubMed]

30. Torroni, A.; Bandelt, H.J.; D’Urbano, L.; Lahermo, P.; Moral, P.; Sellitto, D.; Rengo, C.; Forster, P.; Savontaus, M.L.; Bonné-Tamir, B.; et al. mtDNA analysis reveals a major late Paleolithic population expansion from southwestern to northeastern Europe. Am. J. Hum. Genet. 1998, 62, 1137-1152. [CrossRef] [PubMed]

31. Maixner, F.; Krause-Kyora, B.; Turaev, D.; Herbig, A.; Hoopmann, M.R.; Hallows, J.L.; Kusebauch, U.; Vigl, E.E.; Malfertheiner, P.; Megraud, F.; et al. The 5300-year-old Helicobacter pylori genome of the Iceman. Science 2016, 351, 162-165. [CrossRef] [PubMed]

32. Brussow, H.; Canchaya, C.; Hardt, W.D. Phages and the evolution of bacterial pathogens: From genomic rearrangements to lysogenic conversion. Microbiol. Mol. Biol. Rev. 2004, 68, 560-602. [CrossRef] [PubMed]

33. Feiner, R.; Argov, T.; Rabinovich, L.; Sigal, N.; Borovok, I.; Herskovits, A.A. A new perspective on lysogeny: Prophages as active regulatory switches of bacteria. Nat. Rev. Microbiol. 2015, 13, 641-650. [CrossRef] [PubMed]

34. Los, M.; Wegrzyn, G. Pseudolysogeny. Adv. Virus Res. 2012, 82, 339-349. [PubMed]

35. Golais, F.; Holly, J.; Vitkovska, J. Coevolution of bacteria and their viruses. Folia Microbiol. (Praha) 2013, 58, 177-186. [CrossRef] [PubMed]

36. Wang, X.; Kim, Y.; Ma, Q.; Hong, S.H.; Pokusaeva, K.; Sturino, J.M.; Wood, T.K. Cryptic prophages help bacteria cope with adverse environments. Nat. Commun. 2010, 1, 147. [CrossRef] [PubMed]

37. Wang, X.; Wood, T.K. Cryptic prophages as targets for drug development. Drug Resist. Updat. 2016, $27,30-38$. [CrossRef] [PubMed] 
38. Gama, J.A.; Reis, A.M.; Domingues, I.; Mendes-Soares, H.; Matos, A.M.; Dionisio, F. Temperate bacterial viruses as double-edged swords in bacterial warfare. PLoS ONE 2013, 8, e59043. [CrossRef] [PubMed]

39. Bobay, L.M.; Touchon, M.; Rocha, E.P. Pervasive domestication of defective prophages by bacteria. Proc. Natl. Acad. Sci. USA 2014, 111, 12127-12132. [CrossRef] [PubMed]

40. Touchon, M.; Bernheim, A.; Rocha, E.P. Genetic and life-history traits associated with the distribution of prophages in bacteria. ISME J. 2016, 10, 2744-2754. [CrossRef] [PubMed]

41. Vitoriano, I.; Vitor, J.M.; Oleastro, M.; Roxo-Rosa, M.; Vale, F.F. Proteome variability among Helicobacter pylori isolates clustered according to genomic methylation. J. Appl. Microbiol. 2013, 114, 1817-1832. [CrossRef] [PubMed]

42. Vale, F.F.; Megraud, F.; Vitor, J.M. Geographic distribution of methyltransferases of Helicobacter pylori: evidence of human host population isolation and migration. BMC Microbiol. 2009, 9, 193. [CrossRef] [PubMed]

43. Backert, S.; Kwok, T.; Konig, W. Conjugative plasmid DNA transfer in Helicobacter pylori mediated by chromosomally encoded relaxase and TraG-like proteins. Microbiology 2005, 151, 3493-3503. [CrossRef] [PubMed]

44. Garcia-Aljaro, C.; Balleste, E.; Muniesa, M. Beyond the canonical strategies of horizontal gene transfer in prokaryotes. Curr. Opin. Microbiol. 2017, 38, 95-105. [CrossRef] [PubMed]

45. Fernandez-Gonzalez, E.; Backert, S. DNA transfer in the gastric pathogen Helicobacter pylori. J. Gastroenterol. 2014, 49, 594-604. [CrossRef] [PubMed]

46. Lood, R.; Erturk, G.; Mattiasson, B. Revisiting Antibiotic Resistance Spreading in Wastewater Treatment Plants-Bacteriophages as a Much Neglected Potential Transmission Vehicle. Front. Microbiol. 2017, 8, 2298. [CrossRef] [PubMed]

47. Von Wintersdorff, C.J.; Penders, J.; van Niekerk, J.M.; Mills, N.D.; Majumder, S.; van Alphen, L.B.; Savelkoul, P.H.M.; Wolffs, P.F.G. Dissemination of Antimicrobial Resistance in Microbial Ecosystems through Horizontal Gene Transfer. Front. Microbiol. 2016, 7, 173. [CrossRef] [PubMed]

48. Kuipers, E.J.; Israel, D.A.; Kusters, J.G.; Blaser, M.J. Evidence for a conjugation-like mechanism of DNA transfer in Helicobacter pylori. J. Bacteriol. 1998, 180, 2901-2905. [PubMed]

49. Haas, R.; Meyer, T.F.; van Putten, J.P. Aflagellated mutants of Helicobacter pylori generated by genetic transformation of naturally competent strains using transposon shuttle mutagenesis. Mol. Microbiol. 1993, 8, 753-760. [CrossRef] [PubMed]

50. Stingl, K.; Muller, S.; Scheidgen-Kleyboldt, G.; Clausen, M.; Maier, B. Composite system mediates two-step DNA uptake into Helicobacter pylori. Proc. Natl. Acad. Sci. USA 2010, 107, 1184-1189. [CrossRef] [PubMed]

51. Brussow, H.; Kutter, E. Phage ecology. In Bacteriophages Biology and Applications; Kutter, E., Sulakvelidze, A., Eds.; CRC Press: London, UK, 2005; pp. 129-163.

52. Marshall, B.J.; Armstrong, J.A.; Francis, G.J.; Nokes, N.T.; Wee, S.H. Antibacterial action of bismuth in relation to Campylobacter pyloridis colonization and gastritis. Digestion 1987, 37 (Suppl. 2), 16-30. [CrossRef] [PubMed]

53. Goodwin, C.S.; Armstrong, J.A.; Peters, M. Microbiology of C. pylori. In Campylobacter Pylori in Gastritis and Peptic Ulcer Disease; Blaser, M.J., Ed.; MD.IGAKU-SHOIN: New York, NY, USA, 1989; pp. 25-49.

54. Vale, F.F.; Alves Matos, A.P.; Carvalho, P.; Vitor, J.M. Helicobacter pylori phage screening. Microsc. Microanal. 2008, 14 (Suppl. 3), 150-151. [CrossRef]

55. Schmid, E.N.; von, R.G.; Ansorg, R. Bacteriophages in Helicobacter (Campylobacter) pylori. J. Med. Microbiol. 1990, 32, 101-104. [CrossRef] [PubMed]

56. Heintschel von, H.E.; Nalik, H.P.; Schmid, E.N. Characterisation of a Helicobacter pylori phage (HP1). J. Med. Microbiol. 1993, 38, 245-249.

57. Thiberge, J.M.; Lehours, P.; Bouchier, C.; Ma, L.; Creno, S.; Medigue, C.; Vallene, D.; Ecobichon, C.; Boursaux-Eude, C.; Labigne, A. Sequence of the first Helicobacter pylori strains involved in low-grade Mucosa-Associated Lymphoid Tissue (MALT) Lymphoma. Helicobacter 2006, 11, 02.01.

58. Lehours, P.; Vale, F.F.; Bjursell, M.K.; Melefors, O.; Advani, R.; Glavas, S.; Guegueniat, J.; Gontier, E.; Lacomme, S.; Alves Matos, A.; et al. Genome sequencing reveals a phage in Helicobacter pylori. MBio 2011, 2, e00239-11. [CrossRef] [PubMed]

59. Luo, C.H.; Chiou, P.Y.; Yang, C.Y.; Lin, N.T. Genome, integration and transduction of a novel temperate phage of Helicobacter pylori. J. Virol. 2012, 86, 8781-8792. [CrossRef] [PubMed] 
60. Uchiyama, J.; Takeuchi, H.; Kato, S.; Takemura-Uchiyamaa, I.; Ujiharae, T.; Daibataa, M.; Matsuzakia, S. Complete Genome Sequences of Two Helicobacter pylori Bacteriophages Isolated from Japanese Patients. J. Virol. 2012, 86, 11400-11401. [CrossRef] [PubMed]

61. Uchiyama, J.; Takeuchi, H.; Kato, S.; Gamoh, K.; Takemura-Uchiyama, I.; Ujihara, T.; Daibata, M.; Matsuzaki, S. Characterization of Helicobacter pylori bacteriophage KHP30. Appl. Environ. Microbiol. 2013, 79, 3176-3184. [CrossRef] [PubMed]

62. You, Y.; He, L.; Zhang, M.; Zhang, J. Comparative genomics of a Helicobacter pylori isolate from a Chinese Yunnan Naxi ethnic aborigine suggests high genetic divergence and phage insertion. PLoS ONE 2015, 10, e0120659. [CrossRef] [PubMed]

63. Fan, X.; Li, Y.; He, R.; Li, Q.; He, W. Comparative analysis of prophage-like elements in Helicobacter sp. genomes. PeerJ 2016, 4, e2012. [CrossRef] [PubMed]

64. Kyrillos, A.; Arora, G.; Murray, B.; Rosenwald, A.G. The Presence of Phage Orthologous Genes in Helicobacter pylori Correlates with the Presence of the Virulence Factors CagA and VacA. Helicobacter 2016, 21, $226-233$. [CrossRef] [PubMed]

65. Eppinger, M.; Baar, C.; Linz, B.; Raddatz, G.; Lanz, C.; Keller, H.; Morelli, G.; Gressmann, H.; Achtman, M.; Schuster, S.C. Who ate whom? Adaptive Helicobacter genomic changes that accompanied a host jump from early humans to large felines. PLoS Genet. 2006, 2, e120. [CrossRef]

66. Arnold, I.C.; Zigova, Z.; Holden, M.; Lawley, T.D.; Rad, R.; Dougan, G.; Falkow, S.; Bentley, S.D.; Müller, A. Comparative whole genome sequence analysis of the carcinogenic bacterial model pathogen Helicobacter felis. Genome Biol. Evol. 2011, 3, 302-308. [CrossRef] [PubMed]

67. Schott, T.; Kondadi, P.K.; Hanninen, M.L.; Rossi, M. Comparative genomics of Helicobacter pylori and the human-derived Helicobacter bizzozeronii CIII-1 strain reveal the molecular basis of the zoonotic nature of non-pylori gastric Helicobacter infections in humans. BMC Genom. 2011, 12, 534. [CrossRef] [PubMed]

68. Thiberge, J.M.; Boursaux-Eude, C.; Lehours, P.; Dillies, M.A.; Creno, S.; Coppée, J.Y.; Rouy, Z.; Lajus, A.; Ma, L.; Burucoa, C.; et al. From array-based hybridization of Helicobacter pylori isolates to the complete genome sequence of an isolate associated with MALT lymphoma. BMC Genom. 2010, 11, 368. [CrossRef] [PubMed]

69. Uchiyama, J.; Takemura-Uchiyama, I.; Kato, S.; Takeuchi, H.; Sakaguchi, Y.; Ujihara, T.; Daibata, M.; Shimakura, H.; Okamoto, N.; Sakaguchi, M.; et al. Screening of KHP30-like prophages among Japanese Helicobacter pylori strains, and genetic analysis of a defective KHP30-like prophage sequence integrated in the genome of the H. pylori strain NY40. FEMS Microbiol. Lett. 2016, 363. [CrossRef] [PubMed]

70. Kersulyte, D.; Rossi, M.; Berg, D.E. Sequence divergence and conservation in genomes of Helicobacter cetorum strains from a dolphin and a whale. PLoS ONE 2013, 8, e83177. [CrossRef] [PubMed]

71. Secka, O.; Vale, F.F.; Buissonniere, A.; Thomas, J.E.; Megraud, F.; Lehours, P. Phylogeographic agreement between prophage and bacterial housekeeping genes in Helicobacter pylori strains from The Gambia. Helicobacter 2017, 22, 12394. [CrossRef] [PubMed]

72. Siezen, R.J.; van Hijum, S.A. Genome (re-)annotation and open-source annotation pipelines. Microb. Biotechnol. 2010, 3, 362-369. [CrossRef] [PubMed]

73. Overbeek, R.; Olson, R.; Pusch, G.D.; Olsen, G.J.; Davis, J.J.; Disz, T.; Edwards, R.A.; Gerdes, S.; Parrello, B.; Shukla, M.; et al. The SEED and the Rapid Annotation of microbial genomes using Subsystems Technology (RAST). Nucleic Acids Res. 2014, 42, D206-D214. [CrossRef] [PubMed]

74. Seemann, T. Prokka: Rapid prokaryotic genome annotation. Bioinformatics 2014, 30, 2068-2069. [CrossRef] [PubMed]

75. Delcher, A.L.; Harmon, D.; Kasif, S.; White, O.; Salzberg, S.L. Improved microbial gene identification with GLIMMER. Nucleic Acids Res. 1999, 27, 4636-4641. [CrossRef] [PubMed]

76. Lukashin, A.V.; Borodovsky, M. GeneMark.hmm: New solutions for gene finding. Nucleic Acids Res. 1998, 26, 1107-1115. [CrossRef] [PubMed]

77. Benson, D.A.; Cavanaugh, M.; Clark, K.; Karsch-Mizrachi, I.; Lipman, D.J.; Ostell, J.; Sayers, E.W. GenBank. Nucleic Acids Res. 2017, 45, D37-D42. [CrossRef] [PubMed]

78. UniProt Consortium. Ongoing and future developments at the Universal Protein Resource. Nucleic Acids Res. 2011, 39, D214-D219. 
79. Altschul, S.F.; Madden, T.L.; Schaffer, A.A.; Zhang, J.; Zhang, Z.; Miller, W.; Lipman, D.J. Gapped BLAST and PSI-BLAST: A new generation of protein database search programs. Nucleic Acids Res. 1997, 25, 3389-3402. [CrossRef] [PubMed]

80. Dutilh, B.E.; Backus, L.; Edwards, R.A.; Wels, M.; Bayjanov, J.R.; van Hijum, S.A. Explaining microbial phenotypes on a genomic scale: GWAS for microbes. Brief. Funct. Genom. 2013, 12, 366-380. [CrossRef] [PubMed]

81. Zhou, Y.; Liang, Y.; Lynch, K.H.; Dennis, J.J.; Wishart, D.S. PHAST: A fast phage search tool. Nucleic Acids Res. 2011, 39, W347-W352. [CrossRef] [PubMed]

82. Roux, S.; Enault, F.; Hurwitz, B.L.; Sullivan, M.B. VirSorter: Mining viral signal from microbial genomic data. PeerJ 2015, 3, e985. [CrossRef] [PubMed]

83. Bose, M.; Barber, R.D. Prophage Finder: A prophage loci prediction tool for prokaryotic genome sequences. In Silico Biol. 2006, 6, 223-227. [PubMed]

84. Fouts, D.E. Phage_Finder: Automated identification and classification of prophage regions in complete bacterial genome sequences. Nucleic Acids Res. 2006, 34, 5839-5851. [CrossRef] [PubMed]

85. Lima-Mendez, G.; Van, H.J.; Toussaint, A.; Leplae, R. Prophinder: A computational tool for prophage prediction in prokaryotic genomes. Bioinformatics 2008, 24, 863-865. [CrossRef] [PubMed]

86. Arndt, D.; Grant, J.R.; Marcu, A.; Sajed, T.; Pon, A.; Liang, Y.; Wishart, D.S. PHASTER: A better, faster version of the PHAST phage search tool. Nucleic Acids Res. 2016, 44, W16-W21. [CrossRef] [PubMed]

87. Akhter, S.; Aziz, R.K.; Edwards, R.A. PhiSpy: A novel algorithm for finding prophages in bacterial genomes that combines similarity- and composition-based strategies. Nucleic Acids Res. 2012, 40, e126. [CrossRef] [PubMed]

88. Oliver, S.L.; Lenards, A.J.; Barthelson, R.A.; Merchant, N.; McKay, S.J. Using the iPlant collaborative discovery environment. Curr. Protoc. Bioinform. 2013. [CrossRef] [PubMed]

89. Vale, F.F.; Nunes, A.; Oleastro, M.; Gomes, J.P.; Sampaio, D.A.; Rocha, R.; Vítor, J.M.; Engstrand, L.; Pascoe, B.; Berthenet, E.; et al. Genomic structure and insertion sites of Helicobacter pylori prophages from various geographic origins. Sci. Rep. 2017, 7, 42471. [CrossRef] [PubMed]

90. Hatfull, G.F. Bacteriophage genomics. Curr. Opin. Microbiol. 2008, 11, 447-453. [CrossRef] [PubMed]

91. Soding, J.; Biegert, A.; Lupas, A.N. The HHpred interactive server for protein homology detection and structure prediction. Nucleic Acids Res. 2005, 33, W244-W248. [CrossRef] [PubMed]

92. Cresawn, S.G.; Bogel, M.; Day, N.; Jacobs-Sera, D.; Hendrix, R.W.; Hatfull, G.F. Phamerator: A bioinformatic tool for comparative bacteriophage genomics. BMC Bioinform. 2011, 12, 395. [CrossRef] [PubMed]

93. McNair, K.; Bailey, B.A.; Edwards, R.A. PHACTS, a computational approach to classifying the lifestyle of phages. Bioinformatics 2012, 28, 614-618. [CrossRef] [PubMed]

94. WHO. Global Priority List of Antibiotic-Resistant Bacteria to Guide Research, Discovery, and Development of New Antibiotics; WHO: Geneva, Switzerland, 2017.

95. Roxo-Rosa, M.; Oleastro, M.; Vale, F.F. Helicobacter pylori eradication-The alternatives beyond antibiotics. In Microbial Pathogens and Strategies for Combating Them: Science, Technology and Education; Méndez-Vilas, A., Ed.; Formatex: Badajoz, Spain, 2013; pp. 1656-1667.

96. Cisek, A.A.; Dabrowska, I.; Gregorczyk, K.P.; Wyzewski, Z. Phage Therapy in Bacterial Infections Treatment: One Hundred Years after the Discovery of Bacteriophages. Curr. Microbiol. 2017, 74, 277-283. [CrossRef] [PubMed]

(C) 2018 by the authors. Licensee MDPI, Basel, Switzerland. This article is an open access article distributed under the terms and conditions of the Creative Commons Attribution (CC BY) license (http:/ / creativecommons.org/licenses/by/4.0/). 